\title{
Diet of three sympatric Physalaemus (Anura: Leptodactylidae) from the Brazilian semiarid region
}

Dieta de três Physalaemus simpátricos (Anura: Leptodactylidae) do semiárido brasileiro

\author{
Cicero Ricardo de Oliveiral (1) | Leonides Azevedo Cavalcante"l (1) | Heitor Tavares de Sousa Machado' (1) | \\ Robson Waldemar Ávila' $\bullet$ | Drausio Honorio Morais"' $\bullet$ \\ Universidade Federal do Ceará. Programa de Pós-Graduação em Ecologia e Recursos Naturais. Fortaleza, Ceará, Brasil \\ "Universidade Regional do Cariri. Programa de Pós-Graduação em Diversidade Biológica e Recurso Naturais. Crato, Ceará, Brasil \\ I'IUniversidade Federal de Uberlândia. Instituto de Ciências Agrárias. Monte Carmelo, Minas Gerais, Brasil
}

\begin{abstract}
Studies on the use of food resources and trophic niche of different species can help understand ecological relationships. In this study, we evaluated the diet of three sympatric species of Physalaemus from the Brazilian semiarid. We analyzed a total of 264 individuals, being 100 specimens of Physalaemus albifrons, 93 of $P$. cicada, and 71 of $P$. cuvieri. Seven prey categories were recorded: three for $P$. cicada and $P$. albifrons, and six distinct categories for $P$. cuvieri. The orders Coleoptera, Isoptera and the family Formicidae were the most representative categories in the diet of $P$. cicada, $P$. cuvieri, and $P$. albifrons, respectively. Although there is a high trophic niche overlap, differences in preference for food categories may reduce potential competition in these frog species from the Caatinga.
\end{abstract}

Keywords: Amphibia. Food niche. Arthropods. Physalaemus albifrons. Physalaemus cicada. Physalaemus cuvieri.

Resumo: Estudos sobre o uso de recursos alimentares e nicho trófico em diferentes espécies podem ajudar na compreensão das relações ecológicas. Aqui, avaliamos a dieta de três espécies simpátricas de Physalaemus do semiárido brasileiro. Analisamos um total de 264 indivíduos, sendo 100 espécimes de Physalaemus albifrons, 93 de $P$. cicada e 71 de $P$. cuvieri. Foram registradas sete categorias de presas: três para $P$. cicada e $P$. albifrons, e seis categorias distintas para $P$. cuvieri. As ordens Coleoptera, Isoptera e a família Formicidae foram as categorias mais representativas na dieta de P. cicada, P. cuvieri e $P$. albifrons, respectivamente. Embora haja uma elevada sobreposição de nichos tróficos, as diferenças na preferência das categorias alimentares podem reduzir a potencial competição nestas espécies de anuros na Caatinga.

Palavras-chave: Anfíbios. Nicho alimentar. Artrópodes. Physalaemus albifrons. Physalaemus cicada. Physalaemus cuvieri.

OliVEIRA, C. R., L. A. CAVALCANTE, H. T. S. MACHADO, R. W. ÁVILA \& D. H. MORAIS, 2021. Diet of three sympatric Physalaemus (Anura: Leptodactylidae) from Brazilian semiarid. Boletim do Museu Paraense Emílio Goeldi. Ciências Naturais 16(1): 13-19. DOI: http:// doi.org/10.46357/bcnaturais.v16i1.311.

Autor para correspondência: Cicero Ricardo de Oliveira. Programa de Pós-Graduação em Ecologia e Recursos Naturais. Universidade Federal do Ceará. Centro de Ciências. Campus PICI, Bloco 902. Av. Humberto Monte, s/n. Fortaleza, CE, Brasil. CEP 60455-760 (riccicer@gmail.com).

Recebido em 26/05/2020

Aprovado em 19/10/2020

Responsabilidade editorial: Adriano Oliveira Maciel
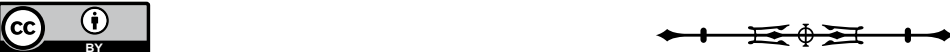


\section{INTRODUCTION}

The genus Physalaemus Fitzinger, 1826, currently comprises 43 species (Segalla et al., 2019), distributed from Mexico to southern South America (Nascimento et al., 2005; Grant et al., 2006; Frost, 2019). Species of this genus inhabiting the Atlantic Forest domain and the phytophysiognomies of the Cerrado, Pantanal, Amazonia, and Caatinga in Brazil (Lisboa \& Haddad, 2009; Caldas et al., 2010; Frost, 2019), occupying a wide variety of microhabitats (Heyer et al., 1990).

Studies with Physalaemus species have been conducted regarding their taxonomy (Heyer \& Wolf, 1989; Feio et al., 1999; Ron et al., 2005; Pimenta et al., 2005), phylogenetic and phylogeography (Lima, 2012). Biological aspects are known mainly from Atlantic Forest and Cerrado areas, and include reproduction (Brasileiro \& Martins, 2006; Pupin et al., 2010), parasitology (Toledo et al., 2013; Campião et al., 2014; Aguiar et al., 2015; Leivas et al., 2018; C. Oliveira et al., 2019), and diet (Santana \& Juncá, 2007; Moser et al., 2017; Leivas et al., 2018). From the Brazilian semiarid, ecological data, especially on diet, are scant.

Dietary studies are important for understanding trophic niche and ecological relationships (Bianchi, 2009; M. Oliveira et al., 2015). Several factors may influence the diet of anurans, including seasonal changes in food availability, competitive relationships, body size, and ecological tolerance of different species (Duellman \& Trueb, 1994).

In this context, the use of different food resources can explain coexistence between species. Thus, our objective is to evaluate the diet of the sympatric species: Physalaemus cicada Bokermann, 1966, Physalaemus cuvieri Fitzinger, 1826, and Physalaemus albifrons Spix, 1824, from Brazilian semiarid.

\section{MATERIAL AND METHODS}

The study was carried out in a Caatinga area in the municipality of Farias Brito (06 51' 55.7" S; $39^{\circ} 32^{\prime}$ 08.0" W), Ceará state, Brazil. The predominant climate of the region is tropical semiarid, with average rainfall of
$896.5 \mathrm{~mm}$ (IPECE, 2015). The samplings were carried out from January to March, 2017, for two days a month.

Specimens were collected by hand in two temporary ponds during visual searches, which consist of walking and visually exploring all possible microhabitats (Bernarde, 2012). Specimens were euthanized following ethical procedures (CFMV, 2013) right after being captured, fixed in 10\% formalin (Calleffo, 2002), and deposited at Coleção Herpetológica of Universidade Regional do Cariri (URCA-H).

A midventral incision was made in all specimens and the contents of the gastrointestinal tract were analyzed under a stereoscopic microscope. All prey items were counted and identified to the lowest possible taxonomic level using specialized literature (Oliveira-Costa, 2011). Fragments that could not be identified due to the high level of digestion were grouped into the category unidentified arthropods (UA).

The length and width of the intact items found in the stomachs were measured with the aid of a digital caliper. Their respective volumes were estimated through the ellipsoid formula:

$$
V=\frac{4 \pi}{3}\left(\frac{\text { length }}{2}\right)\left(\frac{\text { width }}{2}\right)^{2}
$$

To determine the relative contribution of each prey category, the relative importance index was calculated using the following formula (Powell et al., 1990):

$$
R I=\frac{F \%+N \%+V \%}{3}
$$

To demonstrate the relative level of specialization in the diet, we calculate the amplitude of trophic niche, according to Levins' index (Krebs, 1998), which was standardized through the mathematical expression of Hurlbert (1978). To calculate $P_{j}$, we applied the volume values of each food item disregarding the value of unidentified Arthropods (UA). The food overlap was estimated according to Pianka index (Pianka, 1973) considering the RI values. 


$$
B=\frac{1}{\sum p_{j}^{2}} \quad B_{A}=\frac{B-1}{n-1}
$$

We performed a Correspondence Analysis to evaluate prey categories that contributed most to the diet of each species, considering the RI values, disregarding the value of unidentified arthropods (UA), using the PAST 4.02 software.

\section{RESULTS}

We analyzed 264 individuals of Physalaemus, being 100 specimens of Physalaemus albifrons, 93 of $P$. cicada, and 71 of $P$. cuvieri (243 males and 21 females in total, all adults). All specimens captured were in reproductive period. Only 10 individuals of $P$. albifrons (10\%), 13 individuals of $P$. cicada (14\%), and 15 individuals of P. cuvieri (21\%) analyzed presented stomach contents (36 males and two females in total). The stomach contents identified were grouped into seven prey categories.

For Physalaemus albifrons, three prey categories were identified: Formicidae, Coleoptera and Dermaptera. The presence of plant material was also observed. Formicidae was the most frequent (45\%) and important (42\%) prey category. For Physalaemus cicada only Coleoptera was identified, representing $66.8 \%$ of the total volume found. Physalaemus cuvieri presented the highest prey diversity, with six prey categories identified.
Unidentified arthropods (UA) represented the largest volume (90\%). Isoptera was the second most consumed category, with $32.7 \%$ of the number of prey ingested and Relative Importance Index (RI) (14.5\%; Table 1).

Formicidae, Coleoptera, and Isoptera contributed most to the diet of the three species. The correspondence analysis indicated that each species had a greater contribution from a specific category of prey (Figure 1). Overlap between $P$. cicada with $P$. albifrons was 0.67 , and between $P$. cicada with $P$. cuvieri was 0.60 , higher than overlap between $P$. albifrons and $P$. cuvieri 0.40 . Physalaemus cicada presented narrow niche amplitude $\left(B_{A}=0.01\right)$, than $P$. albifrons $\left(B_{A}=0.80\right)$ and $P$. cuvieri $\left(B_{A}=0.25\right)$.

\section{DISCUSSION}

The mating system of anurans includes competition between males (Arak, 1983) or choice of females (Ryan, 1985), in which females are considered a limiting resource to the reproductive success of males (Robertson, 1986; Wogel \& Pombal Jr., 2007). Duellman \& Trueb (1994) stated that many anuran males could remain fasted during the reproductive period, which may explain the low number of specimens with stomach contents in our study. Thus, during the reproductive period males of Physalaemus tend to focus their energy expenditure on reproduction, reducing other activities, such as feeding.

Table 1. Prey items found in the diet of three sympatric Physalaemus in Brazilian semiarid. Legends: V\% = volume; F\% = frequency; $\mathrm{N} \%$ = number; $\mathrm{RI}=$ relative importance index.

\begin{tabular}{|c|c|c|c|c|c|c|c|c|c|c|c|c|}
\hline \multirow{2}{*}{ Prey items } & \multicolumn{4}{|c|}{ P. albifrons } & \multicolumn{4}{|c|}{ P. cicada } & \multicolumn{4}{|c|}{ P. cuvieri } \\
\hline & V\% & $\mathrm{F} \%$ & N\% & RI & V\% & $\mathrm{F} \%$ & $\mathrm{~N} \%$ & $\mathrm{RI}$ & V\% & $\mathrm{F} \%$ & N\% & $\mathrm{RI}$ \\
\hline UA & & & & & 32.9 & 47 & 32.4 & 37.4 & 90 & 55 & 39.4 & 61.5 \\
\hline Coleoptera & 49.7 & 22.2 & 11.8 & 27.9 & 66.8 & 41.2 & 23.5 & 43.9 & 1.5 & 5 & 1 & 2.5 \\
\hline Dermaptera & 23.2 & 22.2 & 11.8 & 19 & & & & & & & & \\
\hline Formicidae & 23.5 & 45.4 & 58.8 & 42.2 & & & & & 6.8 & 15 & 12.5 & 11.4 \\
\hline Isoptera & & & & & & & & & 0.9 & 10 & 32.7 & 14.5 \\
\hline Arthropoda eggs & & & & & 0.3 & 11.8 & 44.1 & 18.7 & 0.1 & 10 & 11.5 & 7.2 \\
\hline Scolopendromorpha & & & & & & & & & 0.8 & 5 & 2.9 & 2.9 \\
\hline
\end{tabular}

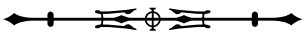




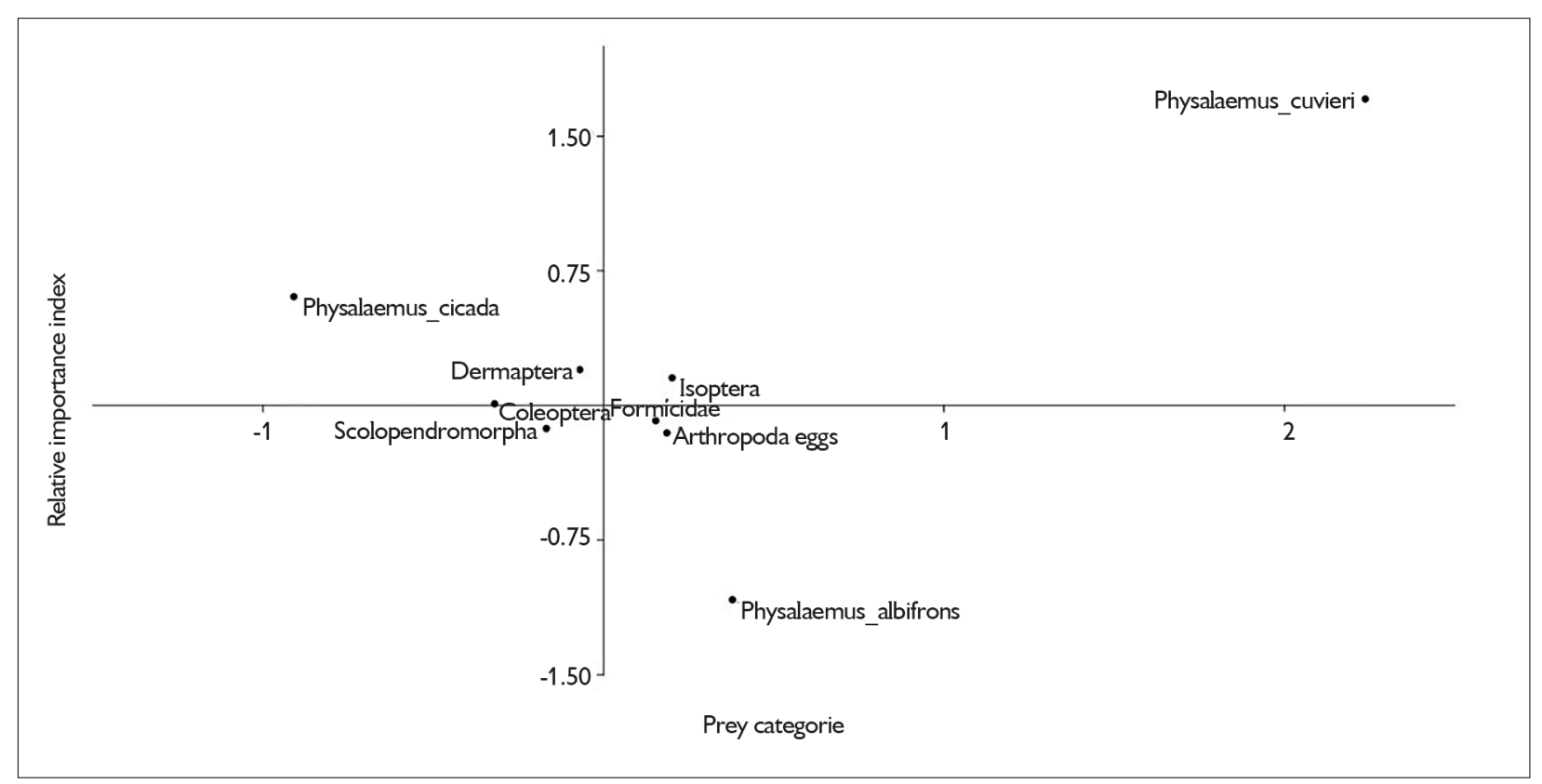

Figure 1. Correspondence analysis for prey categories in the diet of three sympatric Physalaemus in Brazilian semiarid.

Ants are considered of unpleasant taste and metabolically difficult to digest (Hirai \& Marsui, 2000). However, they are frequently consumed by leiuperines, such as Engystomops, Pleurodema and Physalaemus (Narváez \& Ron, 2013; Pincheira-Donoso, 2002; Sousa \& Ávila, 2015; this study). Thus, the preference of Formicidae as the main food observed for $P$. albifrons and $P$. cuvieri is a well documented common pattern within the group, including for P. cicada (Santana \& Juncá, 2007; M. Oliveira et al., 2015; Leivas et al., 2018). In a dietary study of $P$. cicada in the state of Bahia, Northeastern Brazil, Formicidae was the prey category with the highest volume and frequency (Santana \& Juncá, 2007). In our study, P. albifrons consumed three prey categories, being Formicidae the most frequent (45\%) and important (42\%) prey, corroborating the study of Cruz (2000) from São Francisco River sand dunes in the state of Bahia. Moreover, consumption of ants by P. cuvieri and P. albifrons (present study; M. Oliveira et al., 2015), P. cuvieri from Atlantic Forest (Santos et al., 2004; Leivas et al., 2018), P. ephippifer Steindachner, 1864, from the Eastern Amazon (Rodrigues \& Santos-Costa, 2014), and P. albonotatus Steindachner, 1864 (Falico et al., 2012), and P. riograndensis Milstead, 1960 (López et al., 2003), from Argentina, reinforces the importance of this prey category for this genus.

Foraging behavior reflects the availability of local resources (Leivas et al., 2018). This way, individuals tend to have a high predation rate of organisms with terrestrial habits such as ants and termites (Toft, 1980). Moser et al. (2017), in their study of Physalaemus lisei Braun and Braun, 1977, stated that the availability of a given prey could impose opportunistic foraging behavior. The high amount of ants available in the environment enabled a higher comsumption. This can lead to an erroneous interpretation, confusing availability of the item with preference for this food item (Becker et al., 2007).

Herein, the most consumed category for $P$. cuvieri was Isoptera (32.7\%), whereas for P. albifrons was Formicidae (58.8\%), and for $P$. cicada was Coleoptera (23.5\%). Niche amplitude for $P$. albifrons $(B A=0.80)$

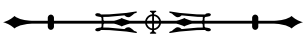


and $P$. cuvieri $(B A=0.25)$ were higher than $P$. cicada $(B A=0.01)$. Also, overlap was higher between $P$. cicada and $P$. albifrons (Oik $=0.67$ ) and between $P$. cicada and $P$. cuvieri (Oik $=0.60)$. These differences in diet may indicate distinct foraging tactics in the analyzed Physalaemus (M. Oliveira et al., 2015). Exploring different items decrease interspecific competition, which allows the coexistence of species in the same niche (AzevedoRamos et al., 1999; Hero et al., 2001).

Among the six categories consumed by P. cuvieri, Isoptera was the most representative arthropod order $(R I=14.5 \%)$, which is in accordance with the studies of Pinto (2011) and Leivas et al. (2018) from Atlantic Forest fragments. Leivas et al. (2018) states that trophic interactions for this species indicate low variation in the diet along its geographic distribution, feeding mainly on arthropods (Formicidae, Isoptera and Araneae). This seems to be a common pattern in the diet of Physalaemus species occurring in Brazil (Santos et al., 2004; M. Oliveira et al., 2015; Moser et al., 2017).

Santana \& Juncá (2007) reported five prey categories for $P$. cicada, with Formicidae being the most representative. In our results, $P$. cicada consumed only Coleoptera $(V=66.8 \%$ and $\mathrm{RI}=43.9 \%)$. This dissimilarity may be result of its small size, which prevents competition with larger congeners in our study area, reducing the diversity of ingested items.

Despite difference between prey types for the anuran species in the present study, there is a considerable niche overlap. Although limited food resources may lead to competition, historical factors are relevant to the configuration of their current foraging tactics (M. Oliveira et al., 2015). Moreover, according to Bassar et al. (2017), the co-occurrence of species initiates a process of rapid evolutionary adaptation in both species, which may minimize potential competition. However, further studies on the food ecology of sympatric amphibians, especially congeners, are necessary to elucidate the mechanisms that allow coexistence.

\section{ACKNOWLEDGEMENTS}

We thank Instituto Chico Mendes de Conservação da Biodiversidade (ICMBio) for collecting permits (56612-1) and the ethics committee of Universidade Regional do Cariri (CEUA/URCA, process number 00260/2016.1). We are also grateful to Fundação Cearense de Apoio ao Desenvolvimento Científico e Tecnológico (FUNCAP), for research grant to H.T.S.M. (process number 8-00344.01.13/18). C.R.O. thanks the Coordenação de Aperfeiçoamento de Pessoal de Nível Superior (CAPES) for his research grant (Process No 88882.454307/2019-01). R.W.A. thanks to Conselho Nacional de Desenvolvimento Científico e Tecnológico (CNPq) for productivity research grant (process number 303622/2015-6; 305988/2018-2) and D.H.M for productivity research grant (process number 313241/2018-0). We thank Aline Angelina for the review and correction of the written text, and we thank the journal reviewers for their valuable considerations on the work.

\section{REFERENCES}

AGUIAR, A., G. M. TOLEDO, L. A. ANJOS \& R. J. SILVA, 2015. Helminth parasite communities of two Physalaemus cuvieri Fitzinger, 1826 (Anura: Leiuperidae) populations under different conditions of habitat integrity in the Atlantic Rain Forest of Brazil. Brazilian Journal of Biology 75(4): 963-968. DOI: https://doi. org/10.1590/1519-6984.03614

ARAK, A., 1983. Male-male competition and mate choice in anuran amphibians. In: P. BATENSON (Ed.): Mate choice: 181210. Cambridge University, Cambridge.

AZEVEDO-RAMOS, C., W. E. MAGNUSSON \& P. BAYLISS, 1999. Predation as the key factor structuring tadpole assemblages in a savanna area in central Amazonia. Copeia 1999(1): 22-33. DOI: https://doi.org/10.2307/1447381

BASSAR, R. D., T. SIMON, W. ROBERTS, J. TRAVIS \& G. N. REZNICK, 2017. The evolution of coexistence: reciprocal adaptation promotes the assembly of a simple community. Evolution 71(2): 373-385. DOI: https://doi.org/10.1111/ evo.13086

BECKER, C. G., F. JONER \& C. R. FONSECA, 2007. Ecologically sustainable tree monocultures contribute to conservation of an Araucaria Forest endemic frog. Journal of Natural History 41(2528): 1739-1752. DOI: https://doi.org/10.1080/00222930701443145 
BERNARDE, P. S., 2012. Anfíbios e répteis: introdução ao estudo da herpetofauna brasileira: 1-320. Anolis Books, Curitiba.

BIANCHI, R. C., 2009. Ecologia de mesocarnívoros em uma área no Pantanal Central, Mato Grosso do Sul. Tese (Doutorado em Ecologia) - Universidade Federal de Mato Grosso do Sul, Campo Grande.

BRASILEIRO, C. A. \& M. MARTINS, 2006. Breeding biology of Physalaemus centralis Bokermann, 1962 (Anura: Leptodactylidae) in southeastern Brazil. Journal of Natural History 40(17-18): 1199-1209. DOI: https://doi.org/10.1080/00222930600835193

CALDAS, F. L. S., C. B. DE-CARVALHO, D. O. SANTANA, R. A. SANTOS, B. D. SILVA \& R. G. FARIA. 2010. Amphibia, Anura, Leiuperidae, Physalaemus cicada Bokermann, 1966: first records fort the state of Sergipe. Check List 6(3): 427-428. DOI: http:// dx.doi.org/10.15560/6.3.427

CALLEFFO, M. E. V., 2002. Anfíbios. In: P. AURICCHIO \& M. G. SALOMÃO (Ed.): Técnicas de coleta e preparação de vertebrados para fins científicos e didáticos: 45-73. Instituto Pau Brasil de História Natural, São Paulo.

CAMPIÃO, K. M., D. H. MORAIS, O. T. DIAS, A. AGUIAR, G. TOLEDO, L. E. R. TAVARES \& R. J. SILVA, 2014. Check list of helminth parasites of amphibians from South America. Zootaxa 3843(1): 1-93. DOI: https://doi.org/10.11646/zootaxa.3843.1.1

CONSELHO FEDERAL DE MEDICINA VETERINÁRIA (CFMV), 2013. Métodos de eutanásia. In: COMISSÃO DE ÉTICA, BIOÉTICA E BEM-ESTAR ANIMAL. Guia brasileiro de boas práticas de eutanásia em animais: 28-29. CFMV, Brasília.

CRUZ, L. C., 2000. Utilização de recursos espaciais e alimentares por Physalaemus albifrons (Anura: Leptodactylidae) nas dunas do Rio São Francisco, Bahia. Monografia (Graduação em Biologia) - Universidade Federal da Bahia, Salvador.

DUELLMAN, W. E. \& L. TRUEB, 1994. Biology of amphibians. Ed. Johns Hopkins, New York.

FALICO, D. A., J. A. LÓPEZ, C. E. ANTONIAZZI \& A. H. BELTZER, 2012. Variación interpoblacional y ontogenética de la dieta de rana llorona Physalaemus albonotatus (Anura: Leiuperidae). Revista Mexicana de Biodiversidad 83(4): 1187-1193.

FEIO, R. N., J. P. POMBAL \& U. CARAMASCHI, 1999. New Physalaemus (Anura: Leptodactylidae) from the Atlantic Forest of Minas Gerais, Brazil. Copeia 1999(1): 141-145. Available at: https:// www.jstor.org/stable/1447394. Accessed on: 26 May 2019.

FROST, D. R., 2019. Amphibian species of the world: an online reference. Version 6.0. American Museum of Natural History, New York, USA. Available at: http://research.amnh.org/herpetology/ amphibia/index.html. Accessed on: 26 May 2019.
GRANT, T., D. R. FROST, J. P. CALDWELL, R. GAGLIARDO, C. F. B. HADDAD, P. J. R. KOK, D. B. MEANS, B. P. NOONAN, W. E. SCHARGEL \& W. WHEELER, 2006. Phylogenetic systematics of dart-poison frogs and their relatives (Amphibia, Athesphatanura, Dendrobatidae). Bulletin of the American Museum of natural History 2006(299): 1-262. DOI: https://doi.org/10.1206/00030090(2006)299[1:PSODFA]2.0.CO;2

HERO, J. M., W. E. MAGNUSSON, C. F. D. ROCHA \& C. P. CATTERALI, 2001. Antipredator defences influence the distribution of amphibian prey species in the central Amazon rain forest. Biotropica 33(1): 131-141. DOI: https://doi.org/10.1111/j.1744-7429.2001. tb00163.x

HEYER, W. \& A. J. WOLF, 1989. Physalaemus crombiei (Amphibia: Leptodactylidae), a new frog species from Espírito Santo, Brazil, with comments on the $P$. signifier group. Proceedings of the Biological Society of Washington 102(2): 500-506.

HEYER, W. R., A. S. RAND, C. A. G. CRUZ, O. L. PEIXOTO \& C. E. NELSON, 1990. Frogs of Boracéia. Arquivos de Zoologia 31(4): 231-410.

HIRAI, T. \& M. MATSUI, 2000. Myrmecophagy in a ranid frog Rana rugosa: specialization or weak avoidance to ant eating. Zoological Science 17(4): 459-466. DOI: https://doi.org/10.2108/02890003(2000)17[459:MIARFR]2.0.CO;2

HURLBERT, S. H., 1978. The measurement of niche overlap and some relatives. Ecology 59(1): 67-77. DOI: https://doi. org/10.2307/1936632

INSTITUTO DE PESQUISA E ESTRATÉGIA ECONÔMICA DO CEARÁ (IPECE), 2015. Perfil Básico Municipal 2015. Available at https://www.ipece.ce.gov.br/wp-content/uploads/sites/45/2018/09/ Farias_Brito_2015.pdf. Accessed on: 3 April 2019.

KREBS, C. J., 1998. Niche measures and resource preferences. In: C. J. KREBS (Ed.): Ecological methodology: 2. ed: 455-495. Benjamin Cummings, Menlo Park, California.

LEIVAS, P. T., F. W. T. LEIVAS \& K. M. CAMPIÃO, 2018. Diet and parasites of the anuran Physalaemus cuvieri Fitzinger, 1826 (Leiuperidae) from an Atlantic Forest fragment. Herpetology Notes 11: 109-113.

LIMA, C. S., 2012. Filogeografia dos anuros Aparasphenodon brunoi e Physalaemus crombiei na região da Mata Atlântica Central. Dissertação (Mestrado em Ciências Biológicas) - Universidade Federal do Espírito Santo, Vitória.

LISBOA, B. S. \& C. F. B. HADDAD, 2009. Amphibia, Anura, Leiuperidae, Physalaemus cicada Bokermann, 1966: Distribution extension and geographic distribution map. Check List 5(3): 699-701. DOI: https://doi.org/10.15560/5.3.699

LÓPEZ, J. A., P. M. PELTZER \& R. C. LAJMANOVICH, 2003. Physalaemus riograndensis (NCN). Diet. Herpetology Review 34: 360-360. 
MOSER, C. F., F. R. AVILA, M. OLIVEIRA \& A. M. TOZETTI, 2017. Diet composition and trophic niche overlap between two sympatric species of Physalaemus (Anura, Leptodactylidae, Leiuperinae) in a subtemperate forest of southern Brazil. Herpetology Notes 10: 9-15.

NARVÁEZ, A. E. \& S. R. RON, 2013. Feeding habits of Engystomops pustulatus (Anura: Leptodactylidae) in Western Ecuador. South American Journal of Herpetology 8(3): 161-167. DOI: https://doi. org/10.2994/SAJH-D-13-00012.1

NASCIMENTO, L. B., U. CARAMASCHI \& C. A. G. CRUZ, 2005. Taxonomic review of the species groups of the genus Physalaemus Fitzinger, 1826 with revalidation of the genera Engystomops JiménezDe-La- Espada, 1872 and Eupemphix Steindachner, 1863 (Amphibia, Anura, Leptodactylidae). Arquivos do Museu Nacional 63(2): 297-320.

OLIVEIRA, C. R., R. W. ÁVILA \& D. H. MORAIS, 2019. Helminths Associated with Three Physalaemus Species (Anura: Leptodactylidae) from Caatinga Biome, Brazil. Acta Parasitologica 64: 205-212. DOI: https://doi.org/10.2478/s11686-018-00022-8

OLIVEIRA, M., M. S. GOTTSCHALK, D. LOEBMANN, M. B. SANTOS, S. MIRANDA, C. ROSA \& A. M. TOZETTI, 2015. Diet composition and niche overlap in two sympatric species of Physalaemus (Anura, Leptodactylidae, Leiuperinae) in coastal subtemperate wetlands. Herpetology Notes 8: 173-177.

OLIVEIRA-COSTA, J., 2011. Entomologia Forense, quando os insetos são vestígios: 3. ed. Ed. Millennium, Campinas.

PIANKA, E. R., 1973. The structure of lizard communities. Annual Review of Ecology and Systematics 4: 53-74. DOI: https://doi. org/10.1146/annurev.es.04.110173.000413

PIMENTA, B. V. S., C. A. G. CRUZ \& D. L. SILVANO, 2005. A new species of the genus Physalaemus Fitzinger, 1826 (Anura: Leptodactylidae) from the Atlantic Rain Forest of Southern Bahia, Brazil. Amphibia-Reptilia 26(2): 201-210. https://doi. org/10.1163/1568538054253483

PINCHEIRA-DONOSO, D., 2002. Nota sobre la alimentacion de Pleurodema bufonina Bell, 1843 (Anura - Leptodac - Tylidae). Gayana (Concepción) 66(1): 7-80. DOI: http://dx.doi.org/10.4067/S071765382002000100011

PINTO, T. M., 2011. Ecologia alimentar de uma taxocenose de anuros terrestres no Brasil Central. Dissertação (Mestrado em Biologia Animal) - Universidade de Brasília, Brasília.

POWELL, J. M., D. ROXAS, J. LAMBOURNE \& S. HOEFS, 1990. Comparison of the feeding value of local browse species. International Livestock Center for Africa, Addis Ababa, Ethiopia.

PUPIN, N. C., J. L. GASPARINI, R. P. BASTOS, C. F. B. HADDAD \& C. P. A. PRADO, 2010. Reproductive biology of an endemic Physalaemus of the Brazilian Atlantic forest and the trade-off between clutch and egg size in terrestrial breeders of the $P$. signifer group. The Herpetological Journal 20(3): 147-156.
ROBERTSON, J. G. M., 1986. Male territoriality, fighting and assessment of fighting ability in the australian frog, Uperoleia rugosa. Animal Behaviour 34(3): 763-772. DOI: https://doi.org/10.1016/ S0003-3472(86)80060-4

RODRIGUES, L. C. \& M. C. SANTOS-COSTA, 2014. Trophic ecology of Physalaemus ephippifer (Anura, Leptodactylidae) in Eastern Amazonia. Journal of Herpetology 48(4): 532-536. DOI: https://doi.org/10.1670/13-142

RON, R. S., L. A. COLOMA \& D. C. CANNATELLA, 2005. A new cryptic species of Physalaemus (Anura: Leptodactylidae) from western Ecuador with comments on the call structure of the $P$. pustulosus species group. Herpetologica 61(2): 178-198.

RYAN, M. J., 1985. The Tungara frog. A study in sexual selection and communication: 1-230. The University of Chicago, Chicago.

SANTANA, A. S. \& F. A. JUNCÁ, 2007. Diet of Physalaemus cf. cicada (Leptodactylidae) and Bufo granulosus (Bufonidae) in a semideciduous forest. Brazilian Journal of Biology 67(1): 125131. DOI: http://dx.doi.org/10.1590/S1519-69842007000100017

SANTOS, E. M., A. V. ALMEIDA \& S. D. VASCONCELOS, 2004. Feeding habits of six anuran (Amphibia: Anura) species in a rainforest fragment in Northeastern Brazil. Iheringia 94(4): 433-438. DOI: http://dx.doi.org/10.1590/S0073-47212004000400014

SEGALLA, M. V., U. CARAMASCHI, C. A. G. CRUZ, T. GRANT, C. F. B. HADDAD, P. C. A. GARCIA, B. V. M. BERNECK \& J. A. LANGONE, 2019. Brazilian amphibians: list of species. Herpetologia Brasileira 8(1): 65-96.

SOUSA, J. G. G. \& R. W. ÁVILA, 2015. Body size, reproduction and feeding ecology of Pleurodema diplolister (Amphibia: Anura: Leiuperidae) from Caatinga, Pernambuco state, Northeastern Brazil. Acta Herpetologica 10(2): 129-134. DOI: https://doi. org/10.13128/Acta_Herpetol-16512

TOFT, C. A., 1980. Feeding ecology of thirteen species of anurans in a seasonal tropical environment. Oecologia 45: 131-141. DOI: https://doi.org/10.1007/BF00346717

TOLEDO, G. M., A. AGUIAR, R. J. SILVA \& L. A. ANJOS, 2013. Helminth fauna of two species of Physalaemus (Anura: Leiuperidae) from an undisturbed fragment of the Atlantic Rainforest, Southeastern Brazil. Journal of Parasitology 99(5): 919-922.

WOGEL, H. \& J. P. POMBAL JR., 2007. Comportamento reprodutivo e seleção sexual em Dendropsophus bipunctatus (Spix, 1824) (Anura, Hylidae). Papéis Avulsos de Zoologia 47(13): 165174. DOI: https://doi.org/10.1590/S0031-10492007001300001 
